\title{
Fetal mesenchymal stem cells: isolation, properties and potential use in perinatology and regenerative medicine
}

\author{
L Gucciardo, ${ }^{a}$ R Lories, ${ }^{b}$ N Ochsenbein-Kölble, ${ }^{a, *}$ E Done', ${ }^{a}$ A Zwijsen, ${ }^{c} J$ Deprest ${ }^{a}$ \\ ${ }^{a}$ Department of Obstetrics and Gynecology and ${ }^{b}$ Rheumatology, University Hospital Gasthuisberg, Leuven, Belgium ${ }^{c}$ Vlaams Instituut voor \\ Biotechnologie (VIB) and Department of Molecular and Developmental Genetics, Laboratory of Developmental Signaling, KU Leuven, Leuven, \\ Belgium \\ Correspondence: Prof J Deprest, Department of Obstetrics and Gynecology, University Hospital Gasthuisberg, Herestraat 49, 3000 Leuven, Belgium. \\ Email jan.deprest@uz.kuleuven.ac.be
}

\begin{abstract}
The fetus is a source of nonembryonic stem cells (SC), with potential applications in perinatal medicine. Cells derived from the placenta, membranes, amniotic fluid or fetal tissues are higher in number, expansion potential and differentiation abilities compared with SC from adult tissues. Although some obstacles keep SC biology at distance from clinical application,
\end{abstract}

the feasibility of using (homologous) SC for tissue engineering for the fetus with a congenital birth defect has been demonstrated. Also, other pathologies may benefit from SC technology.

Keywords Fetal adnexae, stem cell, tissue engineering.

Please cite this paper as: Gucciardo L, Lories R, Ochsenbein-Kölble N, Done’ E, Zwijsen A, Deprest J. Fetal mesenchymal stem cells: isolation, properties and potential use in perinatology and regenerative medicine. BJOG 2009;116:166-172.

\section{Introduction}

Stem cells (SC) have been defined in many different ways. Common denominators are self-renewal, or the ability to generate at least one daughter cell with characteristics similar to the initial cell; potential for multilineage differentiation from a single cell and ability for in vivo functional reconstitution of a given tissue. ${ }^{1}$ The best known SC is the zygote with its ability to give rise to an entire living organism and therefore is considered totipotent. Successive cell divisions make the fertilised egg lose progressively some of its totipotency. At the blastocyst stage, embryonic stem cells (ESCs) isolated from the inner cell mass lose the totipotency of the zygote but are still able to differentiate into the three germ layers. These SCs are considered pluripotent. ${ }^{2}$

An increasing number of SC types have been described in the literature, derived from embryonic, fetal or adult origin. Based on the self-renewal and differentiation abilities, embryo-derived SCs are hierarchically higher than other cell types that have more restricted properties.

${ }^{*}$ Currently working at Department of Obstetrics and Gynecology, University Hospital Zurich, Switzerland.
To characterise post-ESC further, the concept of plasticity was introduced, because adult stem cells (ASC) apparently have a greater self-renewal and differentiation potential than previously thought. ${ }^{3,4}$ There is no consensus yet on the exact definition of plasticity, but minimal criteria are the ability for self-renewal and the ability for both morphologic and functional differentiation into at least one cell type different from the tissue of origin. These abilities might be explained either by fusion of the ASC with other cells allowing transfer of the genetic material between cells and/or nuclear reprogramming. ${ }^{3}$ These hypotheses are very much debated among SC specialists, and for many scientists there is no definitive proof that true pluripotent SCs exist in vivo during postnatal life.

Nonembryonic but plastic SCs open new perspectives for developmental biology and regenerative medicine and their applications may in the near future have a serious impact on medicine.

\section{Antenatal origins of SCs}

The use of fetal or ESC often raises ethical controversies. The controversy started when mouse blastocysts were used to obtain ESC in 1981. ${ }^{5,6}$ Ethical objections were later boosted when ESC were obtained from nonhuman primates, ${ }^{7}$ finally 
resulting in a ban on the use of human ESCs from antenatal origin in many countries. These objections and restrictions are a major obstacle for SC research.

An alternative source of SCs is the isolation of SCs from available fetal tissue samples or postnatally retrieved fetal membranes or placenta. ${ }^{8-18}$ Cells from amniotic fluid and chorionic villi are still key for antenatal diagnosis. ${ }^{19-22}$ The principal SC type isolated from these sources is mesenchymal as they show cell surface markers and morphology that are common with mesenchymal cells from other sources. ${ }^{8,14,16-18}$ They have an expansion potential that is superior than that for adult tissue-derived SCs and are less immunogenic as they do not express human leucocyte antigen (HLA) type 2 surface antigens. The differentiation properties of fetal mesenchymal stem cells (fMSCs) have been very well documented. They have adipogenic, osteogenic and chondrogenic abilities, but differentiation into myocyte, ${ }^{18,23-25}$ neural-like cell ${ }^{16-18,24,26}$ and endothelial tissue have been also described. ${ }^{16,17,27}$

\section{Antenatal sources of SCs}

Invasive fetal sampling is at present the only way to obtain this kind of material during the prenatal period in continuing pregnancies. This is at the expense of (limited) adverse effects.

\section{Fetal blood and fetal haematopoietic SC}

These cells represent $5 \%$ of the CD45+ cells in fetal blood in the first trimester, gradually decreasing with gestational age. ${ }^{9}$ All fetal haematopoietic stem cells (fHSCs) are positive for
CD34 haematopoietic surface antigen. They are probably originating from hemangioblasts, the precursor of haematopoietic and endothelial progenitors, initially located at the aorta-gonad-mesonephros region. They have the ability to produce all haematopoietic lineages. Compared with adult bone-marrow-derived HSCs, fHSCs have a higher cloning efficiency.

\section{Fetal mesenchymal tissues and fMSCs}

MSCs are less frequent than fHSCs. They represent only $0.4 \%$ of first trimester nucleated fetal blood cells and decrease sharply with advancing gestation. No blood-derived fMSCs have been described later than 14 weeks.

MSCs belong to a family of plastic spindle-shaped cells (Figure 1A) with the capacity to differentiate into different mesenchymal tissues., ${ }^{42-31}$ They are present in several fetal tissues such as blood, bone marrow, liver, kidney, lungs and umbilical cord. ${ }^{9-13}$ They do not express haematopoietic or endothelial markers (e.g. CD31 and von Willebrand's factor). However, they display intracellular markers, like fibronectin, laminin, vimentin and mesenchymal markers, like CD105, CD733, CD45, CD34, CD14 and their differentiation potential depends on their site of origin.

fMSCs share with adult MSCs their spindle-shaped fibroblast appearance, the ability to adhere to plastic and to expand ex vivo, which are essential properties for isolation. However, fMSCs expand quicker in vitro than adult MSCs do. Differentiation into adipose, cartilage and osseous tissues as well as transformation into myelosupportive stroma, skeletal,
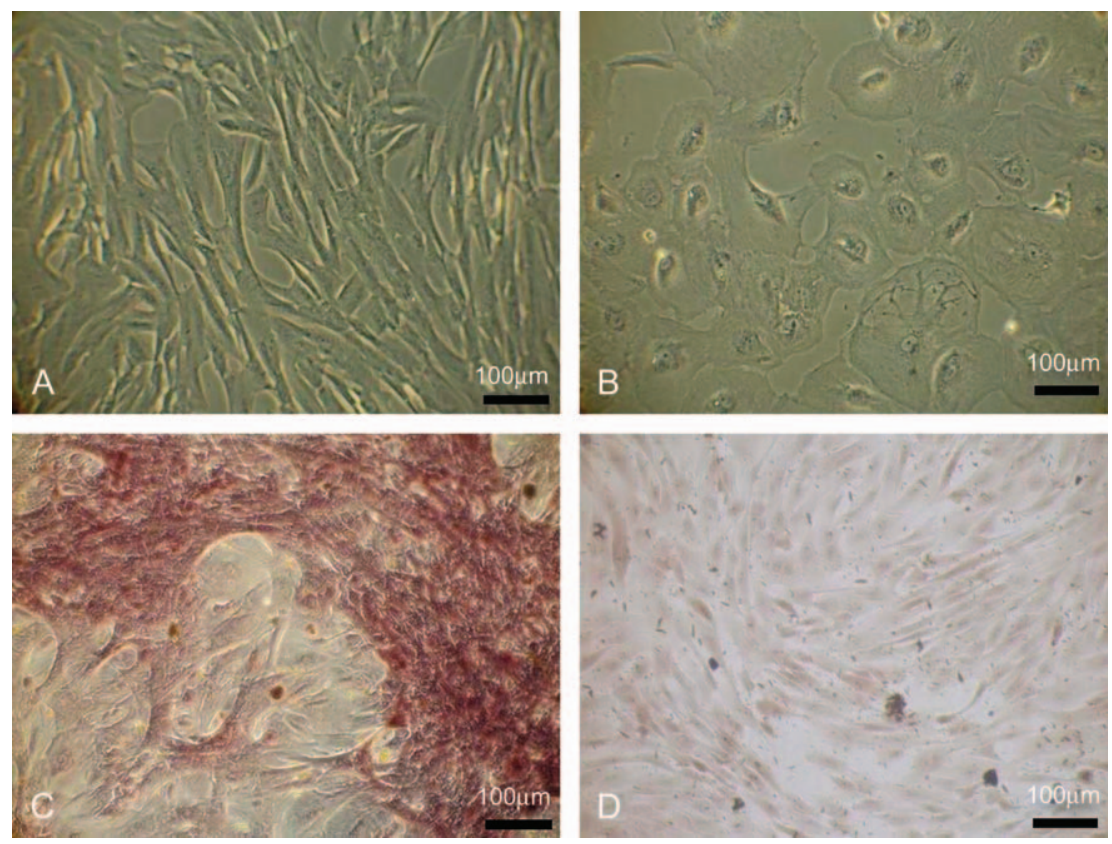

Figure 1. (A) Spindle-shaped human amniotic-fluid-derived MSC after 12-15 cell doublings on gelatine. (B) AF-MSCs cultured with another medium resulting in a different cell morphology. (C) Alizarin Red S staining for in vitro osteogenesis. (D) Oil red staining for adipogenesis. 
cardiac muscle, neural cells and oligodendrocytes have all been documented. ${ }^{9-13,15}$

\section{Different SCs present in the fetal adnexae}

Amniotic fluid contains a great variety of cells from embryonic and extra-embryonic origin. Viable cells present in amniotic fluid may be classified into three groups: (1) epithelioid or 'type E' cells, which originate from skin and urine; (2) amniotic fluid type, originating from the membranes and throphoblast; (3) the 'F-type' originating from fibrous connective tissues and dermal fibroblast. ${ }^{32,33}$ The last type shares markers and properties with MSCs from other sources (Table 1). For that reason, these cells have been called amniotic-fluid-derived MSCs (AF-MSCs) ${ }^{14}$ AF-MSCs express the Oct-4 gene sequence, which is a marker of ESC, and prevents these cells from differentiating. Oct- 4 is expressed in $0.1-0.5 \%$ of amniotic-fluid-derived cells. ${ }^{18}$ Several mesenchymal cell lines have been derived from AF-MSCs, such as adipocytes, osteocytes and neuron-like cells such as neurons, astrocytes and oligodendrocytes..$^{14,16,18}$ There is no widely accepted methodology for isolation of SCs from the amniotic fluid. The variability of the media and/or culture conditions used to select SCs from amniocytes contributes to the variability of the self-renewal and differentiation abilities of AF-MSCs documented in the literature (Figure 1B).

Placenta-derived structures (amnion and chorion) constitute a valuable source of MSCs. ${ }^{8,17}$ The ability to expand SCs from these cells is related to gestational age as SCs tend to be fewer towards the end of pregnancy. But even late in pregnancy, their number and expansion potential remain significantly higher when compared with adult MSCs. Gestational age however does not affect their differentiation potential.

The isolation of cells with SC features from amniotic membranes and fluid opens many new venues for regeneration of tissues, and ultimately even organs. These cells are easily and nearly unrestrictedly available. This is in huge contrast to the small numbers of human adult stem cells and ESCs that can be isolated, and their labour-intensive isolation procedure. The use of these cells is also likely to raise fewer ethical and religious concerns related to the use of the hierarchically higher ESCs. At the time of birth, the fetal membranes remain without function and are normally discarded. In the prenatal period, amniotic fluid becomes available at the time of amniocentesis. During the interval to delivery, these cells could be expanded, to be used after birth, in case the index fetus would require them for reconstruction of a congenital birth defect (i.e. homologous grafting) soon after birth. Furthermore, they can be induced to express organ-specific proteins when transplanted into different targets ${ }^{34}$ and they can function as transgene carriers. It is for this reason that a research consortium has been set up and receives European Commission support through the sixth framework programme (www.euroSTEC.org). As this field has a particular interest to perinatologists, we will expand below on the puzzling question of their origin, the specifics of this SC type and their envisaged applications.

\section{MSCs derived from the fetal adnexea}

\section{Isolation and culture}

In absence of a true consensus, two different approaches stand. One approach is to use cultures, followed by cell sorting. The other uses direct cell sorting, first to obtain a specific population at the onset of culture. In the latter scenario, the heterogeneous 'donor' cell population is processed in a cellsorting device. Following that, sorted cells are easily seeded in culture, even in a single cell protocol. ${ }^{34}$

Several protocols have been described for cell culture. In principle, cells are seeded in a rinsing medium, combined with an antimicrobial solution, growth factors and human- or animal-derived serum. Its composition varies from one group to another. We use a combination of Dulbecco's Modified Eagle's Medium-H/Ham's F12 1:1 (Sigma-Aldrich, Bornem, Belgium), fetal bovine serum (StemCell Technologies Inc., Grenoble, France), penicillin/streptomycin, epidermal growth factor, transferrin, T3 and insulin (Sigma-Aldrich). In our protocol, the cell phenotype is identified by flow cytometry. Fluorescein isothiocyanate- or phycoerythrin-conjugated antibodies against several surface antigens (CD166, CD45, CD105, CD14, CD29, CD34, CD73, CD44 and CD90) are used to mark fMSCs and positive cells are identified by comparing them with isotypic controls (Figure 2). Genetic testing is usually added. Demonstrating certain gene sequences, such

Table 1. Markers and properties of amniotic fluid cell populations

\begin{tabular}{lll}
\hline Epithelioid (E-type) & AF specific 1 (AF-type) & Fibroblastic (F-type) \\
\hline $\begin{array}{l}\text { At the beginning of culture } \\
\begin{array}{l}\text { Quickly significantly } \\
\text { decreasing }\end{array}\end{array}$ & $\begin{array}{l}\text { At the beginning of culture } \\
\text { Persist }\end{array}$ & $\begin{array}{l}\text { Late in culture (=AF-MSCs) } \\
\text { Persist }\end{array}$ \\
& $\begin{array}{l}\text { Oestrogen, progesterone, human chorionic } \\
\text { gonadotrophin HLA-1 }+, \text { HAL-2- }\end{array}$ & CD166, CD105, CD73, CD29, CD44, \\
& Oct-4, HLA-1+, HAL-2-, Oct-4 \\
\hline
\end{tabular}



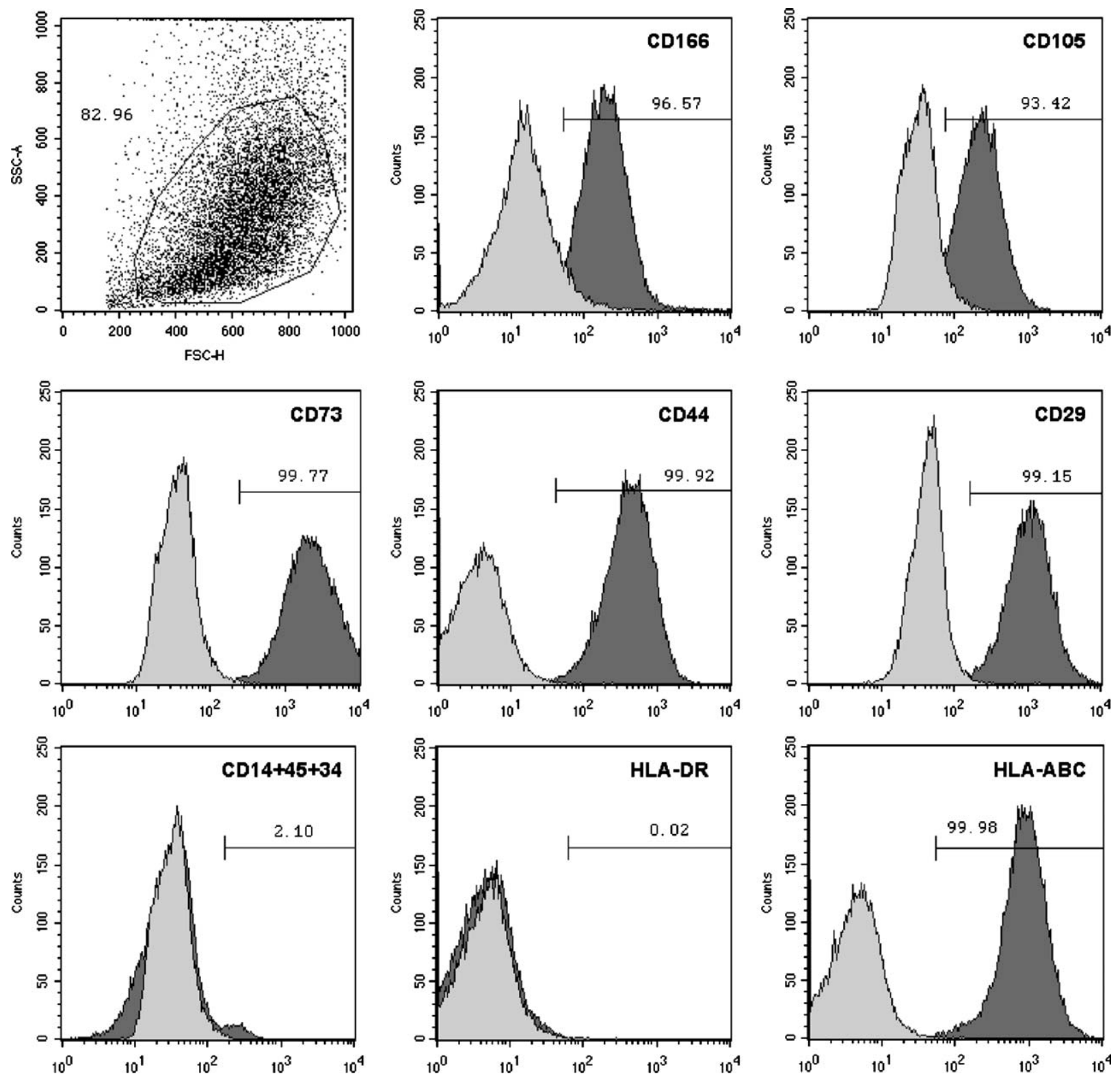

Figure 2. Phenotype analysis of amniotic-fluid-derived MSC. Cells were cultured during three passages and subsequently analysed by Fluorescenceactivated cell sorting (FACS). Cells were labelled with antibodies against CD166, CD105, CD73, CD44, CD29, HLA-ABC, HLA-DR and CD14, CD45, CD34 (dark grey histograms). Isotype control antibodies were used to define background levels (light grey histograms).

as Oct-4 as a marker can be very useful for MSCs identification.

\section{Differentiation abilities}

MSCs can differentiate into osteocytes, ${ }^{8,14,34}$ adipocytes (Figure 1C, D), ${ }^{8,14,34}$ chondrocytes, ${ }^{17}$ myocytes, ${ }^{17,18,34}$ neuron-like cells, ${ }^{16-18,34}$ and endothelial cells ${ }^{17,34}$ that can be demonstrated by morphologic as well functional assessment (Table 2). There are some slight behavioural differences between amnion- and chorion-derived MSCs, for instance, amnion-derived cells differentiate more easily into adipocytes, while chorion-derived SCs differentiate more easily into cartilage, bone, muscle and neural cells.

The presence of proteins typical for certain cell types can be demonstrated by immunohistochemistry and/or Reverse Transcriptase-Polymerase Chain Reaction. Functional differentiation is demonstrated experimentally with 'bioreactors'. Transgenic mice with known inborn deficiencies ${ }^{35,36}$ or with locally induced trauma ${ }^{37}$ are grafted with the candidate SC population with the purpose of demonstrating functional abilities of the latter cells. 
Table 2. Examples of frequently used methods to demonstrate differentiation abilities of stem cells (non-limitative list)

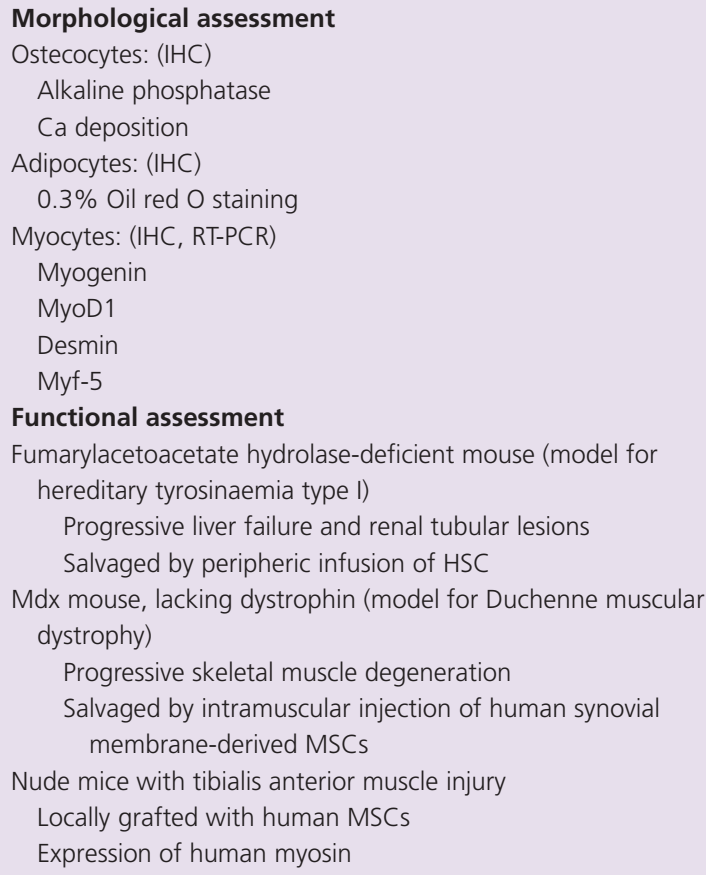

IHC, immunohistochemistry.

\section{Actual and potential applications for cell-derived therapy in perinatal and regenerative medicine}

\section{MSCs and haematological disorders}

HSCs from bone marrow or umbilical cord blood have long been used to re-establish the haematopoietic system following radiation and/or chemotherapy. ${ }^{38,39}$ MSCs produce cytokines, which are important for haematopoiesis and enhancement of engraftment after HSC transplantation. Graft versus host disease is a clinically relevant problem but MSC have immunosuppressive properties that could prevent this rejection process. ${ }^{40-42}$ Transfusion of HSCs with co-transplantation of MSCs has already been shown to be safe within the framework of myeloablative therapies. ${ }^{43}$

\section{Cardiovascular degenerative diseases}

The use of autologous MSC grafts following cardiac infarction has been described with promising results. ${ }^{44}$ Patients suffering from acute myocardial infarction show a significant increase in heart function compared with controls when treated with intracoronary autologous MSCs transfusion. MSC therapy could also decrease the restenosis rate. Furthermore, the potential effect of bone-marrow-derived SCs on the vessel injury repair process is at present the subject of different experimental therapies. ${ }^{45,46}$

\section{Applications in genetic and neurological disorders}

Genetic deficiencies are logical candidate disorders. In osteogenesis imperfecta, genetic mutations are responsible for a specific type 1 collagen deficiency, causing multiple osteoarticular complications, such as painful fractures and bone deformations. Amelioration in bone brittleness has been reported by several groups using donor bone marrow transplants or MSC from first trimester fetal blood. ${ }^{47,48}$ Additionally, MSCs can differentiate into neurons and astrocytes, which could be used for symptomatic treatment of amyotrophic lateral sclerosis (ALS). ${ }^{49}$ Patients with ALS have a progressive decline in muscular function because of the loss of motor neurons. Intraspinal injection of autologous bonemarrow-derived MSCs has significantly slowed down the loss of muscular strength. ${ }^{49}$ Lysosomal storage diseases are characterised by accumulation of endogenic toxic substances which is often lethal. Patients with Hurler syndrome (mucopolysaccharidosis) and metachromatic leucodystrophy develop significant skeletal and neurological defects. The natural course of degradation has been shown to slow down by peripheric injection of allogeneic MSCs. ${ }^{50}$

\section{SCs and tissue engineering}

When repairing congenital or acquired structural defects, often the use of prosthetic material is required. Prosthetic materials carry the risk of potential complications, such as microbial colonisation and subsequent infection, failure of tissue in-growth or structural integrity, absence of functional properties, induction of adhesions and in growing children, the prosthesis may not meet the increasing size requirements of adulthood, prompting re-intervention at a later stage.

Acellular collagen matrices and cellular grafts may theoretically overcome some of these problems. ${ }^{51}$ Mature cells are not an appropriate choice because of their short lifespan and their inability for self-renewal. SCs with their remarkable proliferation and differentiation properties are theoretically better candidates. ${ }^{52}$ For prenatally diagnosed structural defects, there is the opportunity of obtaining homologous cells at the time of invasive sampling, like chorionic villi biopsy, amniocentesis or cordocentesis. Redundant or purposely obtained fetal cells could be harvested, cultured and manipulated in vitro, during the remainder of pregnancy and later used for tissue engineering of graft material that will be used for postnatal reconstruction. Proof of principle has already been demonstrated for experimental neonatal reconstruction of a congenital diaphragmatic defect. ${ }^{53,54}$ Although conceptually simple, the process is very complex. The composition of such a 'functional' graft requires a few essential components. First, there is the cellular component with viable, responsive and phenotypically stable as well as nonimmunogenic cells. Next, there is a matrix required for maximal cell adherence as well as to offer sufficient tensile 
strength and appropriate viscoelasticity. The nature of the matrix, the mechanical forces and present electromagnetic fields are important variables for ultimate cell growth and behaviour. ${ }^{55}$ So far, the design of an ideal reconstructive mesh has been shown to be problematic in itself, already in the absence of cells seeded on it. Conceptually, an ideal construction as well as the addition of bioactive substances such as growth factors or gene vectors may be tools enhancing structural and functional regeneration. We have shown that a heterologous, amnionderived cell-free scaffold could enhance the wound healing process of fetoscopy-induced membrane trauma. ${ }^{56}$

Feasibility of the use of homologous MSC for tissue engineering has also been demonstrated. Fauza and colleagues obtained fMSCs from amniotic fluid and myoblasts from fetal skeletal muscle biopsy and used these to engineer a bioprosthesis, which after birth was used to correct an earlier induced diaphragmatic defect. ${ }^{54}$ Along the same lines, experimental bladder augmentation was performed in a lamb model for bladder extrophy. ${ }^{57}$ Homologous cells from fetal bladder biopsy were expanded and used after birth, to correct the bladder defect. fMSCs have also been used as an adjuvant in peripheral nerve injury in adult rats. ${ }^{58}$ In these experiments, typically amniotic fluid was used as a source of cells. Clinically, this is very realistic as in most congenital birth defects, invasive sampling for karyotyping is often required and redundant cells could be used for tissue engineering. Theoretically, fetal skin and skeletal muscle biopsies can also serve as an autologous source of material for tissue engineering applications.

\section{Challenges for the future}

SC applications may become important in reconstructive surgery in the perinatal period but a considerable number of obstacles remain. These include fundamental questions about SC physiology, the relation between SCs and their direct environment, the expression of SCs markers, the mechanisms controlling differentiation, the functional abilities of SCs derived from different sources, the susceptibility of SC to ageing or apoptosis and the mechanisms guiding or improving migration of SC to the injury site. There are, however, more basic and logistic questions, such as efficient protocols for the generation of huge numbers of the desired cell types in a pure form, or even more basic, regulatory issues relating to the media used, which today are typically from bovine origin. These issues keep SC biology to some distance from clinical application, but do not compromise their huge potential.

\section{Disclosure of interests}

There are no conflicts of interests to disclose.

\section{Contribution to authorship}

L.G. and J.D. wrote the paper and all authors commented on the paper.

\section{Funding}

Work and stipends (L.G., E.D.) is supported by the European Commission in its 6th Framework and the Marie Curie programme (MEST CT2005 019707; EuroSTEC; LSHC-CT-2006-037409)). J.D.P. is a Clinical Researcher funded by the Fonds voor Wetenschappelijk Onderzoek Vlaanderen (1.8.012.07.N.02). N.O.-K. was supported by grants of the Swiss National Science Foundation.

\section{References}

1 Weissman IL. Translating stem and progenitor cell biology to the clinic: barriers and opportunities. Science 2000;287:1442-6.

2 Eckfeldt CE, Mendenhall EM, Verfaillie CM. The molecular repertoire of the 'almighty' stem cell. Nat Rev Mol Cell Biol 2005;6:726-37.

3 Verfaillie CM. Adult stem cells: assessing the case for pluripotency. Trends Cell Biol 2002;12:502-8.

4 Pittenger MF, Mackay AM, Beck SC, Jaiswal RK, Douglas R, Mosca JD, et al. Multilineage potential of adult human mesenchymal stem cells. Science 1999;284:143-7.

5 Martin GR. Isolation of a pluripotent cell line from early mouse embryos cultured in medium conditioned by teratocarcinoma stem cells. Proc Natl Acad Sci U S A 1981;78:7634-8.

6 Evans MJ, Kaufman MH. Establishment in culture of pluripotential cells from mouse embryos. Nature 1981;292:154-6.

7 Thomson JA, Itskovitz-Eldor J, Shapiro SS, Waknitz MA, Swiergiel JJ, Marshall VS, et al. Embryonic stem cell lines derived from human blastocysts. Science 1998;282:1145-7.

8 In 't Anker PS, Scherjon SA, Kleijburg-van der Keur C, Groot-Swings GM, Claas FH, Fibbe WE, et al. Isolation of mesenchymal stem cells of fetal or maternal origin from human placenta. Stem Cells 2004;22:1338-45.

9 Campagnoli C, Roberts IA, Kumar S, Bennett PR, Bellantuono I, Fisk NM. Identification of mesenchymal stem/progenitor cells in human first-trimester fetal blood, liver, and bone marrow. Blood 2001; 98:2396-402.

10 Noort WA, Kruisselbrink AB, in't Anker PS, Kruger M, van Bezooijen RL, de Paus RA, et al. Mesenchymal stem cells promote engraftment of human umbilical cord blood-derived CD34(+) cells in NOD/SCID mice. Exp Hematol 2002;30:870-8.

11 In 't Anker PS, Noort WA, Scherjon SA, Kleijburg-van der Keur C, Kruisselbrink $A B$, van Bezooijen $R L$, et al. Mesenchymal stem cells in human second-trimester bone marrow, liver, lung, and spleen exhibit a similar immunophenotype but a heterogeneous multilineage differentiation potential. Haematologica 2003;88:845-52.

12 Almeida-Porada G, El Shabrawy D, Porada C, Zanjani ED. Differentiative potential of human metanephric mesenchymal cells. Exp Hematol 2002;30:1454-62.

13 Hu Y, Liao L, Wang Q, Ma L, Ma G, Jiang $X$, et al. Isolation and identification of mesenchymal stem cells from human fetal pancreas. J Lab Clin Med 2003;141:342-9.

14 In't Anker PS, Scherjon SA, Kleijburg-van der Keur C, Noort WA, Claas FH, Willemze $\mathrm{R}$, et al. Amniotic fluid as a novel source of mesenchymal stem cells for therapeutic transplantation. Blood 2003;102:1548-9.

15 O'Donoghue K, Fisk NM. Fetal stem cells. Best Pract Res Clin Obstet Gynaecol 2004;18:853-75.

16 Tsai MS, Lee JL, Chang YJ, Hwang SM. Isolation of human multipotent mesenchymal stem cells from second-trimester amniotic fluid using a novel two-stage culture protocol. Hum Reprod 2004;19:1450-6.

17 Miao Z, Jin J, Chen L, Zhu J, Huang W, Zhao J, et al. Isolation of mesenchymal stem cells from human placenta: comparison with human bone marrow mesenchymal stem cells. Cell Biol Int 2006;30:681-7.

18 Bossolasco P, Montemurro T, Cova L, Zangrossi S, Calzarossa C, Buiatiotis $\mathrm{S}$, et al. Molecular and phenotypic characterization of human 
amniotic fluid cells and their differentiation potential. Cell Res 2006; 16:329-36.

19 Tabor A, Philip J, Madsen M, Bang J, Obel EB, Norgaard-Pedersen B. Randomised controlled trial of genetic amniocentesis in 4606 low-risk women. Lancet 1986;1:1287-93.

20 Sundberg K, Bang J, Smidt-Jensen S, Brocks V, Lundsteen C, Parner J, et al. Randomised study of risk of fetal loss related to early amniocentesis versus chorionic villus sampling. Lancet 1997;350:697-703.

21 Borrell A, Fortuny A, Lazaro L, Costa D, Seres A, Pappa S, et al. Firsttrimester transcervical chorionic villus sampling by biopsy forceps versus mid-trimester amniocentesis: a randomized controlled trial project. Prenat Diagn 1999;19:1138-42.

22 Philip J, Silver RK, Wilson RD, Thom EA, Zachary JM, Mohide P, et al. Late first-trimester invasive prenatal diagnosis: results of an international randomized trial. Obstet Gynecol 2004;103:1164-73.

23 Chan J, Waddington SN, O'Donoghue K, Kurata H, Guillot PV, Gotherstrom C, et al. Widespread distribution and muscle differentiation of human fetal mesenchymal stem cells after intrauterine transplantation in dystrophic mdx mouse. Stem Cells 2007;25: 875-84.

24 Jeong JA, Gang EJ, Hong SH, Hwang SH, Kim SW, Yang IH, et al. Rapid neural differentiation of human cord blood-derived mesenchymal stem cells. Neuroreport 2004;15:1731-4.

25 Gang EJ, Jeong JA, Hong SH, Hwang SH, Kim SW, Yang IH, et al. Skeletal myogenic differentiation of mesenchymal stem cells isolated from human umbilical cord blood. Stem Cells 2004;22:617-24.

26 Portmann-Lanz CB, Schoeberlein A, Huber A, Sager R, Malek A, Holzgreve W, et al. Placental mesenchymal stem cells as potential autologous graft for pre- and perinatal neuroregeneration. Am J Obstet Gynecol 2006;194:664-73.

27 Gang EJ, Jeong JA, Han S, Yan Q, Jeon CJ, Kim H. In vitro endothelial potential of human UC blood-derived mesenchymal stem cells. Cytotherapy 2006;8:215-227.

28 Zuk PA, Zhu M, Ashjian P, De Ugarte DA, Huang Jl, Mizuno H, et al. Human adipose tissue is a source of multipotent stem cells. Mol Biol Cell 2002;13:4279-95

29 Zvaifler NJ, Marinova-Mutafchieva L, Adams G, Edwards CJ, Moss J, Burger JA, et al. Mesenchymal precursor cells in the blood of normal individuals. Arthritis Res 2000;2:477-88.

30 Nakahara H, Dennis JE, Bruder SP, Haynesworth SE, Lennon DP, Caplan Al. In vitro differentiation of bone and hypertrophic cartilage from periosteal-derived cells. Exp Cell Res 1991;195:492-503.

31 Nathanson MA. Bone matrix-directed chondrogenesis of muscle in vitro. Clin Orthop Relat Res 1985::142-58.

32 Hoehn H, Salk D. Morphological and biochemical heterogeneity of amniotic fluid cells in culture. Methods Cell Biol 1982;26:11-34.

33 Gosden CM. Amniotic fluid cell types and culture. Br Med Bull 1983; 39:348-54

34 De Coppi P, Bartsch G, Siddiqui MM, Xu T, Santos CC, Perin L, et al. Isolation of amniotic stem cell lines with potential for therapy. Nat Biotechnol 2007;25:100-6.

35 Lagasse E, Connors H, Al Dhalimy M, Reitsma M, Dohse M, Osborne L, et al. Purified hematopoietic stem cells can differentiate into hepatocytes in vivo. Nat Med 2000;6:1229-34.

36 De Bari C, Dell'Accio F, Vandenabeele F, Vermeesch JR, Raymackers JM, Luyten FP. Skeletal muscle repair by adult human mesenchymal stem cells from synovial membrane. J Cell Biol 2003;160:909-18.

37 De Bari C, Dell'Accio F, Vanlauwe J, Eyckmans J, Khan IM, Archer CW, et al. Mesenchymal multipotency of adult human periosteal cells demonstrated by single-cell lineage analysis. Arthritis Rheum 2006: 54:1209-21.

38 Bhatia M, Wang JC, Kapp U, Bonnet D, Dick JE. Purification of primitive human hematopoietic cells capable of repopulating immune-deficient mice. Proc Natl Acad Sci U S A 1997:94:5320-5.
39 Osawa M, Hanada K, Hamada H, Nakauchi H. Long-term lymphohematopoietic reconstitution by a single CD34-low/negative hematopoietic stem cell. Science 1996;273:242-5.

40 Gotherstrom C, Ringden O, Tammik C, Zetterberg E, Westgren M, Le Blanc K. Immunologic properties of human fetal mesenchymal stem cells. Am J Obstet Gynecol 2004;190:239-45.

41 Le Blanc K. Immunomodulatory effects of fetal and adult mesenchymal stem cells. Cytotherapy 2003;5:485-9.

42 Le Blanc K, Pittenger M. Mesenchymal stem cells: progress toward promise. Cytotherapy 2005;7:36-45.

43 Lazarus HM, Haynesworth SE, Gerson SL, Rosenthal NS, Caplan AI. Ex vivo expansion and subsequent infusion of human bone marrowderived stromal progenitor cells (mesenchymal progenitor cells): implications for therapeutic use. Bone Marrow Transplant 1995;16:557-64.

44 Chen SL, Fang WW, Ye F, Liu YH, Qian J, Shan SJ, et al. Effect on left ventricular function of intracoronary transplantation of autologous bone marrow mesenchymal stem cell in patients with acute myocardial infarction. Am J Cardiol 2004;94:92-5.

45 Tanaka K, Sata M, Hirata Y, Nagai R. Diverse contribution of bone marrow cells to neointimal hyperplasia after mechanical vascular injuries. Circ Res 2003;93:783-90.

46 Aoki J, Serruys PW, van Beusekom H, Ong AT, McFadden EP, Sianos G, et al. Endothelial progenitor cell capture by stents coated with antibody against CD34: the HEALING-FIM (Healthy Endothelial Accelerated Lining Inhibits Neointimal Growth-First In Man) Registry. J Am Coll Cardiol 2005;45:1574-9.

47 Guillot PV, Abass O, Bassett JH, Shefelbine SJ, Bou-Gharios G, Chan J, et al. Intrauterine transplantation of human fetal mesenchymal stem cells from first-trimester blood repairs bone and reduces fractures in osteogenesis imperfecta mice. Blood 2008;111:1717-1725.

48 Horwitz EM, Prockop DJ, Fitzpatrick LA, Koo WW, Gordon PL, Neel M, et al. Transplantability and therapeutic effects of bone marrow-derived mesenchymal cells in children with osteogenesis imperfecta. Nat Med 1999;5:309-13.

49 Mazzini L, Mareschi K, Ferrero I, Vassallo E, Oliveri G, Boccaletti R, et al. Autologous mesenchymal stem cells: clinical applications in amyotrophic lateral sclerosis. Neurol Res 2006:28:523-6.

50 Koc ON, Day J, Nieder M, Gerson SL, Lazarus HM, Krivit W. Allogeneic mesenchymal stem cell infusion for treatment of metachromatic leukodystrophy (MLD) and Hurler syndrome (MPS-IH). Bone Marrow Transplant 2002;30:215-222.

51 Kaviani A, Guleserian K, Perry TE, Jennings RW, Ziegler MM, Fauza DO. Fetal tissue engineering from amniotic fluid. J Am Coll Surg 2003;196: 592-7.

52 Leo AJ, Grande DA. Mesenchymal stem cells in tissue engineering. Cells Tissues Organs 2006;183:112-122.

53 Fuchs JR, Kaviani A, Oh JT, LaVan D, Udagawa T, Jennings RW, et al. Diaphragmatic reconstruction with autologous tendon engineered from mesenchymal amniocytes. J Pediatr Surg 2004;39:834-8.

54 Kunisaki SM, Fuchs JR, Kaviani A, Oh JT, LaVan DA, Vacanti JP, et al. Diaphragmatic repair through fetal tissue engineering: a comparison between mesenchymal amniocyte- and myoblast-based constructs. J Pediatr Surg 2006;41:34-39.

55 Ikada Y. Challenges in tissue engineering. J $R$ Soc Interface 2006;3: 589-601.

56 Portmann-Lanz CB, Ochsenbein-Kolble N, Marquardt K, Luthi U, Zisch A, Zimmermann R. Manufacture of a cell-free amnion matrix scaffold that supports amnion cell outgrowth in vitro. Placenta 2007;28:6-13.

57 Fauza DO, Fishman SJ, Mehegan K, Atala A. Videofetoscopically assisted fetal tissue engineering: bladder augmentation. J Pediatr Surg 1998;33:7-12

58 Pan HC, Yang DY, Chiu YT, Lai SZ, Wang YC, Chang MH, et al. Enhanced regeneration in injured sciatic nerve by human amniotic mesenchymal stem cell. J Clin Neurosci 2006;13:570-5. 